Article

\title{
Impact of Mine Panel Size on Hydraulic Permeability of Weakly Cemented Strata
}

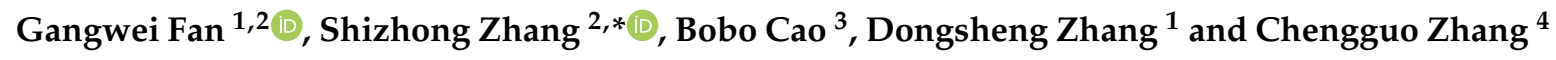 \\ 1 State Key Laboratory of Coal Resources and Safe Mining, China University of Mining \& Technology, \\ Xuzhou 221116, China; fangw@cumt.edu.cn (G.F.); dshzhang123@cumt.edu.cn (D.Z.) \\ 2 School of Mines, China University of Mining \& Technology, Xuzhou 221116, China \\ 3 Ordos Haohua Clean Coal Co. Ltd, Ordos, Inner Mongolia 017205, China; kdcaobobo@163.com \\ 4 School of Minerals and Energy Resources Engineering, The University of New South Wales, Sydney 2052, \\ Australia; chengguo.zhang@unsw.edu.au \\ * Correspondence: zhangshizhong@cumt.edu.cn; Tel.: +86-183-6126-2484
}

Received: 21 February 2020; Accepted: 17 March 2020; Published: 19 March 2020

check for updates

\begin{abstract}
The effect of underground coal mining on groundwater, ranging from minimal to severe depending on the mined-out panel size, is primarily associated with the change in ground hydraulic permeability. This paper presents a novel panel design method, taking consideration of reducing water loss during the mining operation, which is based on evaluating and ranking the impact of panel size on the hydraulic permeability of weakly cemented strata. The permeability test results of weakly cemented rock samples collected in the Yili No.4 Coal Mine in Xinjiang, China strongly indicates that, in contrast to common rock, their post-peak permeability during the total stress-strain process is lower than the initial permeability due to high porosity and the presence of clay minerals. A numerical modeling based on strain-permeability functions reveals that the post-mining permeability distribution in the weakly cemented overlying strata could be subdivided into three zones: the permeability reduction zone, the permeability restoring zone, and the permeability high-increment zone. The impact significance of different size factors on the post-mining permeability of overlying strata can be ranked in decreasing order as follows: mining height, panel width, and panel length, the quantification of which was based on the variance analysis of such indices as maximum pore pressure and maximum flow velocity. Based on the above findings, the optimal size of panel 21103 in the Yili No.4 Coal Mine was determined and validated by water level field observations.
\end{abstract}

Keywords: weakly cemented rock; post-mining permeability; impact significance; panel size; field observations

\section{Introduction}

In recent years, with the continuous improvement of coal mining technologies and equipment, panel size is increasing annually, and the single production capacity record is being permanently refreshed. For example, the maximum panel width has reached $450 \mathrm{~m}$ in China and $482 \mathrm{~m}$ in the United States; the maximum continuous advance length has attained $6000 \mathrm{~m}$ in China, with the mining height exceeding $20 \mathrm{~m}$, and $6858 \mathrm{~m}$ in the US [1]. The current design theory for coal mining seeks to adapt the existing conditions of the coal resources and the level of technical equipment to ensure greater safety, productivity, and efficiency, without a comprehensive analysis of the bearing capacity of water resources in mining areas and their impact on coal production conditions [2,3].

However, overlying strata collapse and mining-induced fractures caused by underground coal mining may lead to a series of ecological problems, such as the decline of the aquifer water level, the loss of shallow water resources, and the desertification of land [4-7]. In China, such problems are 
frequent in coal mines in the North Shaanxi, Huanglong, Shendong, Ningdong, and Xinjiang provinces of northwest China, which are located in arid and semi-arid areas with scarce surface and groundwater resources and a fragile ecological environment [8-10]. These coal seams are shallow and thick, and the formation is weakly cemented and soft due to late diagenesis. Therefore, coal mining in these fields is more sensitive to the impact of overlying strata and water resources. The resultant serious imbalance between coal mining activities, water resources, and the environment is quite hazardous. Thus, mining activities in North Shaanxi decreased the water level of the overlying strata in goaf and caused 19 of the 20 available springs in the $131 \mathrm{~km}^{2}$ area of the Daliuta Coal Mine to dry up after ten years of mining (from 1996 to 2006). In the Zhangjiamao Coal Mine, 102 of 115 the springs were dried up by mining, decreasing the mine water by $98.2 \%$. In particular, the water-abundant Mingaitugou spring flow dropped by $72 \%$, and the Muhegou spring ran dry [11].

In the process of underground mining, with the mine-out space accumulation, the rock permeability varies with the deformation and failure of overlying strata, as well as the development of fractures. Finally, it may cause a loss of the water-resisting function and water resources in the aquiclude [12]. Considering this, the rock permeability variation under the influence of mining space accumulation can be used as the key index to predict the impact of underground mining on water resources, which is also the basis for optimizing the mining layout and technological parameters based on the protection water resources in the mining area.

At present, numerous studies have been conducted on the permeability variation of the overlying strata in mining, which generally link the deformation, fracture development, porosity variation, and stress state of the overlying strata [13-15]. For example, Wachtel et al. reported that mining caused strain variation in the overlying strata, which led to changes in permeability, and quantitatively analyzed potential changes in permeability caused by room and pillar mining through the event tree analysis model [16]. Das demonstrated that fractures in the overlying strata extend upward, leading to a large increase in rock permeability after mining [17]. Nourani et al. and Poulsen et al. revealed that the overlying strata permeability was directly related to porosity and proposed a method for rock permeability evaluation based on the porosity parameters [18,19]. Wang et al. and Karacan et al. reported that rocks in the goaf gradually supported the overlying roof with the panel advance, while the stress redistribution in the overlying strata caused the overlying rock permeability decline $[20,21]$.

In addition, several researchers have studied the impact of some mining parameters on the permeability of the overlying strata. Thus, Karacan and Goodman reported that the permeability variation of the overlying strata is closely related to the mining rate of the panel, and that the latter was negatively correlated with an increase in the overlying strata permeability [22]. Previous studies mainly focused on the impact of mining size on overlying strata movement and the development height of the fracture zone [23,24]. For example, Palchik and Majdi et al. reported that the heights of destressed and caved zones were directly related to the mining height, and derived the respective calculation formulas $[25,26]$. Weng et al. proved that the fractured water-conducting zone height in the overlying strata was not only positively correlated with the mining height, but also increased with the panel width gain [27]. Feng et al. proved that the height of the fractured water-conducting zone in the overlying strata was positively correlated with the volume of the coal produced [28]. Follington and Isaac and Dumpleton found that the failure zone height and surface subsidence decreased with the panel width reduction $[29,30]$. Earlier studies of aquifer water level protection also revealed that the overlying strata movement and fracture development of the aquiclude could be reduced by adjusting the mining height, panel size, and advance speed [31,32]. Although the mining height, panel width, and panel length influencing factors are known to control the overlying strata movement, a multi-factor analysis of these factors has not yet been performed. Therefore, a comprehensive account of the mining height, panel width, and advance distance is attempted in this study of the impact of coal mining on the permeability of the overlying strata and shallow water resources.

Firstly, based on the geological conditions of a weakly cemented coal seam in the Yili No.4 Coal Mine in Xinjiang, China, the respective strain-permeability function was derived by a permeability test under 
triaxial compression. This was then used in the numerical model of the overlying strata deformation and permeability variation during mining. Based on the proposed model, three mining factors, namely mining height, panel width, and panel length, were taken into consideration comprehensively. The impact of the panel size on the permeability of the overlying strata was evaluated by taking the pore pressure difference and flow velocity of the aquiclude as measuring indices, which can provide a reference for the panel design in which water conservation is taken into consideration.

\section{Permeability Test of Weakly Cemented Rocks}

\subsection{Materials and Methods}

\subsubsection{Materials}

Rock samples were collected from the overlying strata of panel 21103 of the Yili No.4 Coal Mine in Xinjiang, China, which is characterized by late diagenesis and poor cementation (as shown in Figure 1a). The primary aquifer was mainly composed of Quaternary gravel, while the main aquiclude consisted of Paleogene mudstone. The sampling sites corresponded to Paleogene mudstone and sandstone, and their buried depths were 30-35 and 35-85 m, respectively. During the field sampling, the XY-42, XY-44, HXY-1500 drilling rigs and related supporting equipment were used, and the rock samples were obtained by drilling to 30-35 $\mathrm{m}$ and 35-85 m, respectively, via the method of vertical drilling into the ground. The comprehensive columnar section and sampling location of panel 21103 are shown in Figure $1 b$.

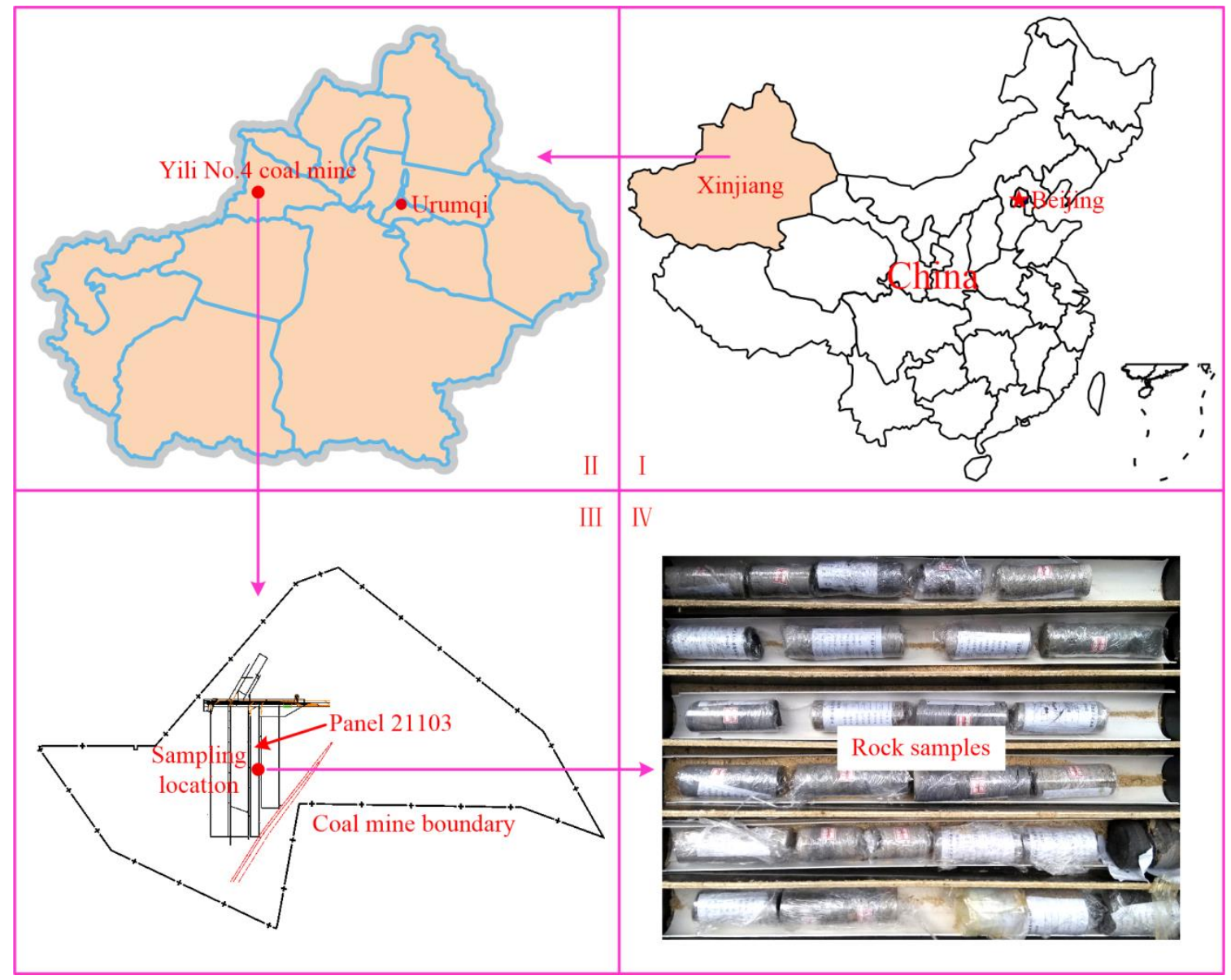

(a)

Figure 1. Cont. 


\begin{tabular}{|c|c|c|c|c|}
\hline STRATUM & COLUMN & LITHOLOGY & THICKNESS & REMARK \\
\hline $\begin{array}{c}\text { Quaternary } \\
(\mathrm{Q})\end{array}$ & Silt layer & $20 \mathrm{~m}$ & \\
\hline \multirow{3}{*}{$\begin{array}{c}\text { Paleogene } \\
\text { (E) }\end{array}$} & Gravel layer & $10 \mathrm{~m}$ & Aquifer \\
\hline & & Mudstone & $5 \mathrm{~m}$ & Aquiclude \\
\hline \multirow{3}{*}{$\begin{array}{c}\text { Jurassic } \\
\text { (J) }\end{array}$} & Sandstone & $50 \mathrm{~m}$ & \\
\hline & Mudstone & $10 \mathrm{~m}$ & \\
\hline
\end{tabular}

I Sampling location

(b)

Figure 1. Sampling location and rock conditions: (a) panel location and sampling results; (b) the comprehensive geological column of panel 21103.

\subsubsection{Methods}

First, mudstone and sandstone samples were obtained by drilling in the field. Then, standard samples for the rock permeability tests were prepared in the laboratory and treated with water saturation before the test. Based on the transient method, permeability variations of weakly cemented mudstone and sandstone were studied during the total stress-strain process under triaxial compression using an MTS815 electro-hydraulic servo-controlled rock mechanics testing system. The latter included the data collection system, hydraulic control system, and loading system, as illustrated in Figure 2.

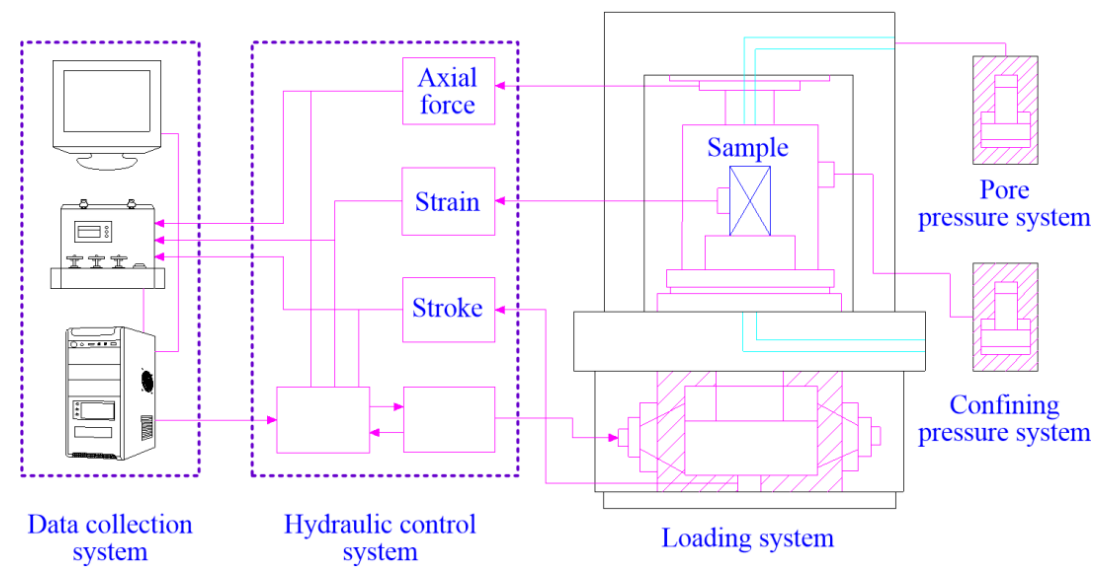

Figure 2. MTS815 testing system.

During the test, the confining pressure and osmotic pressure difference remained constant while the rack permeability during the total stress-strain process was tested. In compliance with the actual in-situ stress measurements, the sample confining pressure was set at $3 \mathrm{MPa}$. Firstly, the confining pressure was raised to $3 \mathrm{MPa}$ to simulate the original stress, and the initial permeability of the sample was tested under static water conditions. Then, the axial force was applied, and the displacement-controlled loading method was adopted to test the permeability of the rock samples at all stages until the residual stress stage (RSS). The loading test design parameters are listed in Table 1. 
Table 1. Loading test design parameters.

\begin{tabular}{cccccc}
\hline \multirow{2}{*}{ Rock } & Attribute & \multirow{2}{*}{$\begin{array}{c}\text { Confining } \\
\text { Pressure (MPa) }\end{array}$} & $\begin{array}{c}\text { Osmotic Pressure } \\
\text { Difference (MPa) }\end{array}$ & \multicolumn{2}{c}{ Loading Rate (mm/min) } \\
\cline { 5 - 7 } Sandstone & - & 3 & 2 & Pre-Peak & Post-Peak \\
\hline Mudstone & Aquiclude & 3 & 2 & 0.03 & 0.01 \\
\hline
\end{tabular}

\subsection{Results and Discussion}

\subsubsection{Results}

The stress-strain-permeability variations of weakly cemented mudstone and sandstone during the total stress-strain process are depicted in Figure 3 (Table S1).

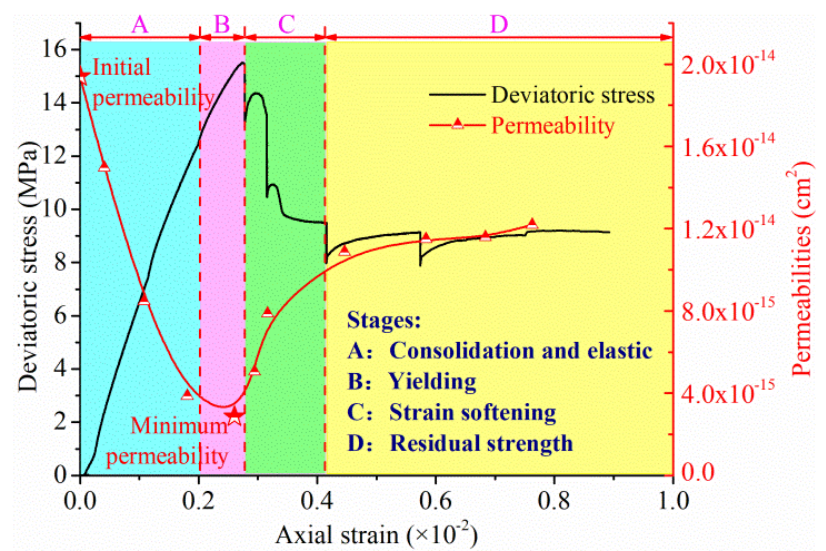

(a)

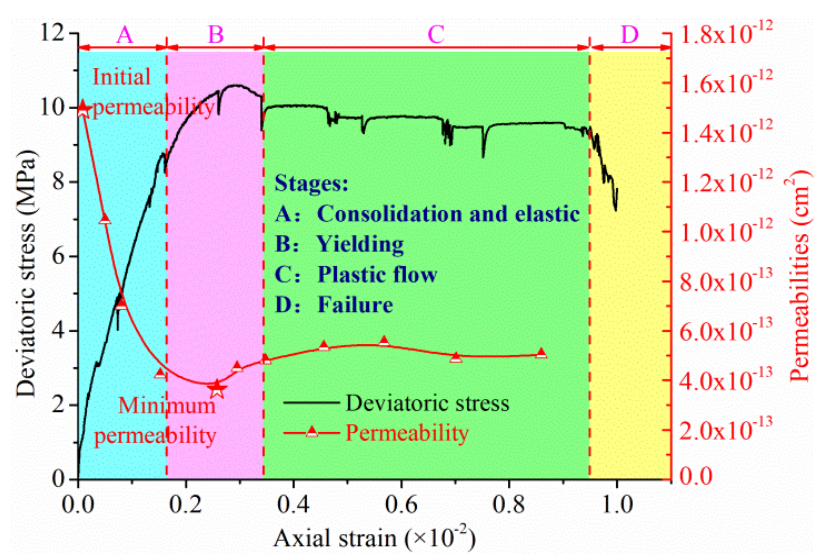

(b)

Figure 3. The stress-strain-permeability curve of samples during the total stress-strain process: (a) mudstone; (b) sandstone.

The stress-strain curve of weakly cemented mudstone in Figure $3 \mathrm{a}$ can be subdivided into the following four stages: (1) the consolidation and elastic stage; (2) the yielding stage; (3) the strain softening stage; and (4) the residual strength stage [33]. At the first stage (consolidation and elastic) stage, the stress basically increases linearly with the strain gain, and micro-cracks and pores in the sample are gradually compressed, while the permeability decreases sharply with the strain. After entering the second (yielding) stage, the decline rate of permeability gradually drops. The strain corresponding to the lowest value of permeability is less than that of the stress peak; that is, the permeability valley is ahead of the stress peak, and the permeability rises after reaching the valley value. The third (strain 
softening) stage occurs after the peak stress is reached, and the permeability gradually transfers from a rapid rise to a slow one. Moreover, the permeability of the RSS gradually increases, but the residual permeability is lower than the initial one.

The stress-strain curve of weakly cemented sandstone can be subdivided into four stages: (1) the consolidation and elastic stage; (2) the yielding stage (3) the plastic flow stage (PFS); and (4) the failure stage, as shown in Figure 3b. The permeability decreases sharply with strain at the first (consolidation and elastic) stage. After the second (yielding) stage, the decline rate of the permeability gradually drops down, and the permeability valley is ahead of the stress peak, which is identical to the pattern of weakly cemented mudstone samples. In contrast, weakly cemented sandstone has a long period of elastic-plastic deformation at the post-peak stage, the so-called "stress plateau", where the stress remains almost unchanged with strain gain, while the permeability at this stage remains nearly constant after a slight rise. Unfortunately, the test system did not allow capture of the permeability value after the sample failure.

Given this, the permeability ranges of mudstone and sandstone were assessed to be $10^{-15}-10^{-14} \mathrm{~cm}^{2}$ and $10^{-13}-10^{-12} \mathrm{~cm}^{2}$, respectively. The permeability of mudstone is seen to be lower than that of sandstone by two orders of magnitude, which implies its higher water resistance. The statistical data on permeability for each stage are summarized in Table 2 . The initial and minimum permeability values are $k_{0}$ and $k_{\min }$, respectively, while, the average permeabilities of mudstone at the RSS stage and sandstone at the PFS stage are abbreviated as $k_{\text {ave. }}$. In the total stress-strain process, the permeability magnitude changes as follows: initial permeability $>$ average permeability at RSS or PFS $>$ minimum permeability (i.e., $k_{0}>k_{\text {ave }}>k_{\text {min }}$ ). The initial permeability values of mudstone and sandstone were maximal and exceeded their minimal values by 6.78 and 4.11 times, respectively. At the RSS stage, the permeability of mudstone increased greatly, its average RSS value exceeding the minimum permeability by 4.03 times. At the PFS stage, the sandstone permeability increase was small, its average value exceeding the minimum permeability by only 1.43 times.

Table 2. The permeability parameters of each stage in the total stress-strain process.

\begin{tabular}{cccccc}
\hline Rock & $\begin{array}{c}\text { Initial } \\
\text { Permeability } \\
\left(\boldsymbol{k}_{\mathbf{0}} / \mathbf{c m}^{\mathbf{2}}\right)\end{array}$ & $\begin{array}{c}\text { Minimum } \\
\text { Permeability } \\
\left(\boldsymbol{k}_{\min } / \mathbf{c m}^{2}\right)\end{array}$ & $\begin{array}{c}\text { Permeability at RSS } \\
\text { or PFS }\left(\boldsymbol{k}_{\text {ave }} / \mathbf{c m}^{\mathbf{2}}\right)\end{array}$ & $\boldsymbol{k}_{\mathbf{0}} / \boldsymbol{k}_{\min }$ & $\boldsymbol{k}_{\text {ave }} / \boldsymbol{k}_{\text {min }}$ \\
\hline Mudstone & $1.9406 \times 10^{-14}$ & $2.8617 \times 10^{-15}$ & $1.1531 \times 10^{-14}$ & 6.78 & 4.03 \\
Sandstone & $1.4920 \times 10^{-12}$ & $3.6296 \times 10^{-13}$ & $5.1920 \times 10^{-13}$ & 4.11 & 1.43 \\
\hline
\end{tabular}

Where RSS is residual stress stage and PFS is plastic flow stage.

\subsubsection{Discussion}

The permeability test results show that weakly cemented sandstone exhibits obvious plastic deformation during the test, while its permeability at this stage remains practically unchanged. Moreover, the initial permeability values of weakly cemented mudstone and sandstone are larger than those corresponding to the peak and residual strength values. Similarly, the permeability at the RSS or PFS stages also remains constant, in contrast to the non-weakly cemented rock of the same lithology. For example, Liu et al. and Zhang et al. found that the initial permeability of non-weakly cemented mudstone and sandstone during the total stress-strain process was very small, and much lower than their post-peak permeability values [34,35]. Meanwhile, the permeability of rocks at the post-peak stage shows an obvious downward trend, depicted in Figure 4. 


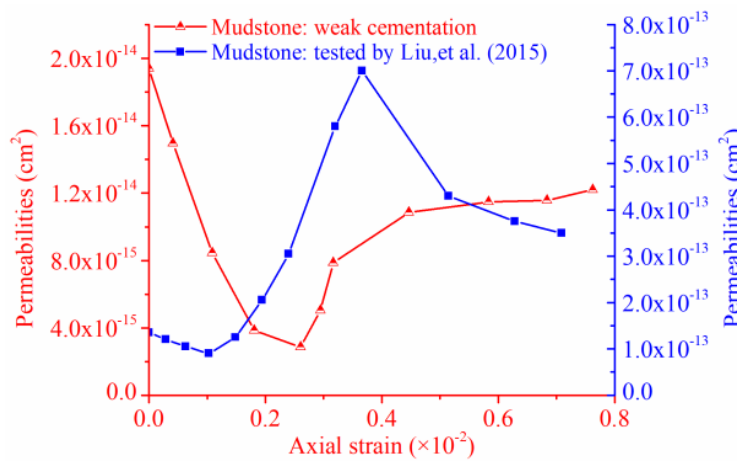

(a)

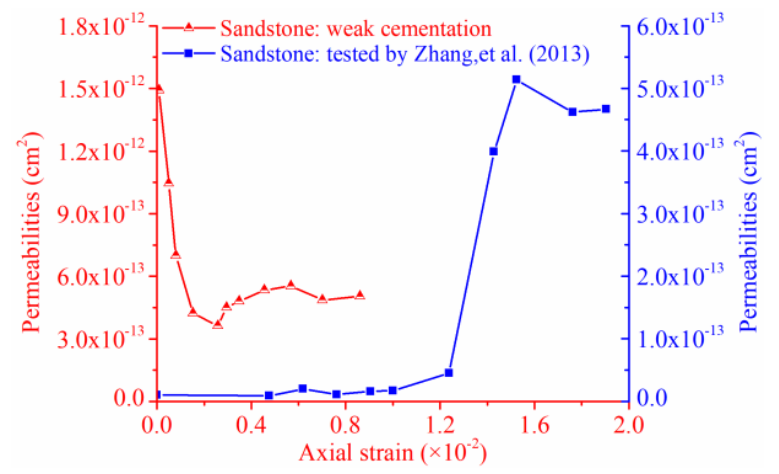

(b)

Figure 4. Permeability differences between weakly cemented and common rocks: (a) mudstone; (b) sandstone.

\section{Characterization of Microstructure and Mineral Composition}

In order to identify the source of the different permeability variations of weakly cemented rocks and their mechanism, the microstructure and mineral composition of weakly cemented mudstone and sandstone were tested by SEM and XRD, respectively. The determination of the mineral composition of rock samples was based on the X-ray diffraction pattern of samples and the principle of XRD phase identification. The analysis of mineral composition consisted of phase determination and content determination. On the basis of obtaining the X-ray diffraction pattern of the rock sample, the phases were identified by comparing the X-ray diffraction pattern of the sample with those of known rocks in the database. Next, the content of each mineral was determined via the XRD diffraction intensity of each phase, which was directly proportional to the phase content. Jade software was used to facilitate the above analysis, the results of which are depicted in Figure 5.

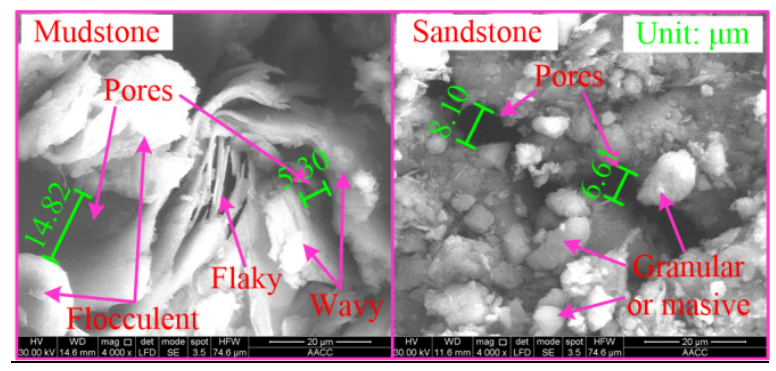

(a)

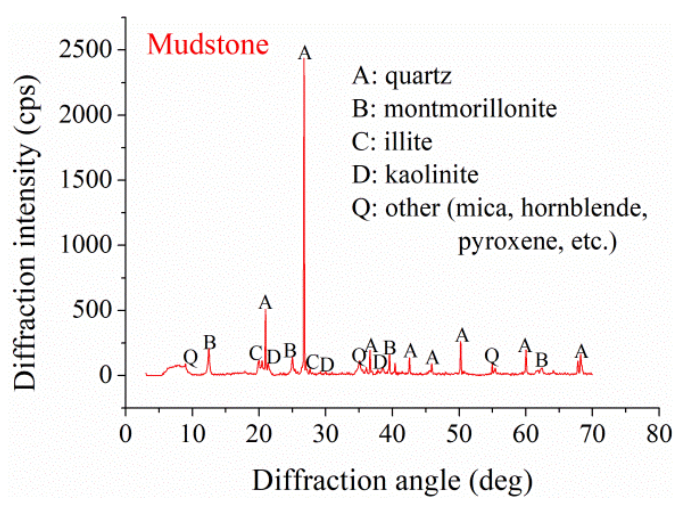

(b)

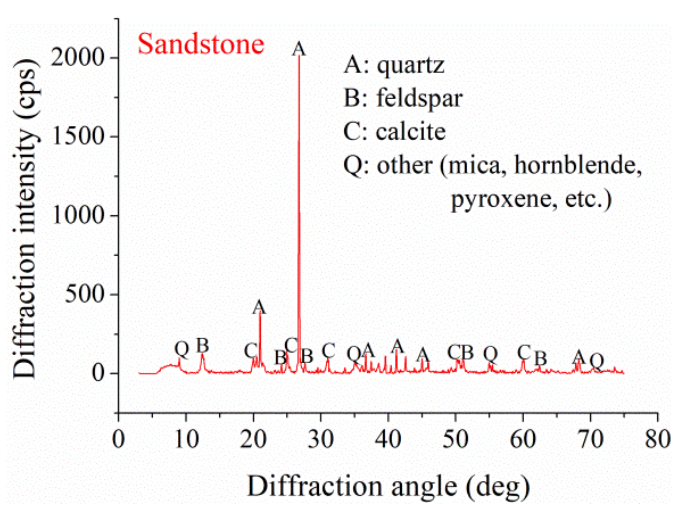

(c)

Figure 5. Test results of microstructure and mineral composition: (a) microstructural characteristics (magnification $4000 \times$ ); (b) X-ray diffraction pattern of mudstone; (c) X-ray diffraction pattern of sandstone. 
As shown in Figure 5a, weakly cemented mudstone and sandstone have significant internal pores, poor cementation, high initial porosity, and natural seepage channels. The pore sizes of mudstone and sandstone are different, ranging from $5.30 \mu \mathrm{m}$ to $14.82 \mu \mathrm{m}$ and $6.61 \mu \mathrm{m}$ to $8.10 \mu \mathrm{m}$, respectively. What's more, mudstone contains clay-rich minerals, such as flocculent and worm-like kaolinite, flaky illite, and silk-spun and wavy montmorillonite, etc., while sandstone is rich in feldspar and calcite with granular or massive structure. In addition, there are many holes and granular minerals in sandstone.

As seen in Figure $5 b, c$, the main component of mudstone is quartz, accounting for $80.7 \%$ of the total mineral content. Besides, it contains clay-rich minerals, such as montmorillonite, illite, and kaolinite, their content being equal to $7.0 \%, 2.4 \%$, and $1.4 \%$, respectively; while the total content of clay minerals is $10.8 \%$. The quartz content of sandstone is $87.6 \%$, exceeding that of mudstone by $5.2 \%$. Besides, it contains feldspar and calcite, accounting for $5.2 \%$ and $4.6 \%$ of the total mineral content, respectively. It is noteworthy that mudstone and sandstone also contain a small amount of mica and other mineral components. The quantitative assessment of mineral compositions is presented in Table 3.

Table 3. Mineral composition of rock samples.

\begin{tabular}{ccccccccc}
\hline \multicolumn{4}{c}{ Mudstone (\%) } & \multicolumn{5}{c}{ Sandstone (\%) } \\
\hline Quartz & Montmorillonite & Illite & Kaolinite & Other & Quartz & Feldspar & Calcite & Other \\
80.7 & 7.0 & 2.4 & 1.4 & 8.5 & 85.9 & 5.2 & 4.6 & 4.3 \\
\hline \multicolumn{2}{c}{ Clay minerals } & & 10.8 & & Clay minerals & - \\
\hline
\end{tabular}

Discussion of the Permeability Variation Mechanism

Under hydrostatic pressure, weakly cemented mudstone and sandstone have very high porosity and a low cementation degree. As a result, their initial permeability values can be the maximum of the total stress-strain process. At the compaction and elastic stage, the permeability of mudstone and sandstone decreases rapidly with the gradual compaction of their initial pores. There are some significant differences in permeability between mudstone and sandstone after entering the elastic-plastic stage. Micro-cracks in mudstone gradually initiate and propagate after entering the elastic-plastic stage, and the permeability increases obviously. At the residual strength stage, while internal fractures in mudstone continue to develop, some fractures formed at earlier stages stage start to close again. Meanwhile, clay-rich minerals, such as montmorillonite and illite in mudstone, expand and get muddy after their contact with water, which also closes part of the permeability passage, resulting in the basically unchanged permeability of mudstone at this stage, as shown in Figure 3a. In the case of sandstone, after entering the elastic-plastic stage, the stress plateau is reached, which is consistent with that observed in the case of triaxial compression of porous sandstone. This may be a manifestation of compression zone formation, which is the result of pore collapse and particle crushing during the formation of the compression zone [36,37]. During this period, the permeability variation of specimens is controlled by the dual impacts of porosity closure, leading to permeability reduction and particle crushing, resulting in the permeability rise. When these two impacts are in balance, the permeability remains unchanged, as shown in Figure 3b.

In addition, mudstone contains clay-rich minerals, such as montmorillonite, kaolin, and illite, accounting for $10.8 \%$ of the total content. In contrast, the clay mineral composition of sandstone is not obvious. Due to the dilation and muddiness of clay minerals in contact with water, some seepage cracks can be closed, which may be one of the reasons that mudstone permeability is lower by two orders of magnitude than that of sandstone, and its water resistance is more significant.

\subsection{Strain-Permeability Curve Fitting}

On the basis of permeability variation in rocks, the best function fitting of permeability variation in weakly cemented mudstone and sandstone constructed for the total stress-strain process was carried 
out in this study using a quadric polynomial. The functional dependence between volume strain and permeability was obtained and plotted, as shown in Figure 6.

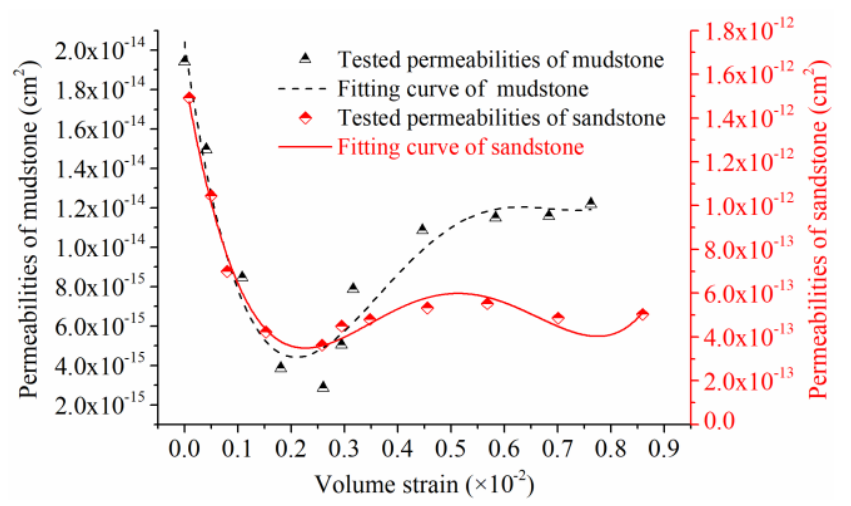

Figure 6. The fitting curve of the strain-permeability of weakly cemented rocks.

As seen in Figure 6, the variation trend of the fitting curve is in good agreement with the measured results on permeability, which reflects the basic mechanism of permeability variation during the total stress-strain process. The fitting form of permeability variation function of the two is as follows:

$$
k=k_{1}+\mathrm{A}_{1} \varepsilon+\mathrm{A}_{2} \varepsilon^{2}+\mathrm{A}_{3} \varepsilon^{3}+\mathrm{A}_{4} \varepsilon^{4}
$$

where $k$ is rock permeability, and $\varepsilon$ is strain.

The fitting results for the permeability function parameters of weakly cemented mudstone and sandstone are listed in Table 4 . The values of $\mathrm{R}^{2}$ of these two fitting functions are 0.9122 and 0.9792 , respectively. Since both exceed not only the required level of 0.90 but even 0.95 , this strongly indicates that the function fits well with the measured results, and can adequately represent the functional relationship between the permeability and strain of weakly cemented mudstone and sandstone during the total stress-strain process.

Table 4. The fitting results for the permeability function parameters.

\begin{tabular}{|c|c|c|c|c|c|c|c|}
\hline \multirow{2}{*}{ Rock } & \multicolumn{5}{|c|}{ Unknown Quantities } & \multirow{2}{*}{$\begin{array}{l}\text { Residual Sum } \\
\text { of Squares }\end{array}$} & \multirow{2}{*}{$\begin{array}{c}\text { Adj. } \\
\text { R-Square }\end{array}$} \\
\hline & $k_{1}$ & $\mathbf{A}_{1}$ & $\mathbf{A}_{2}$ & $\mathbf{A}_{3}$ & $\mathbf{A}_{4}$ & & \\
\hline Mudstone & $2.041 \times 10^{-14}$ & $-1.885 \times 10^{-13}$ & $7.272 \times 10^{-13}$ & $-1.018 \times 10^{-12}$ & $4.846 \times 10^{-13}$ & $1.282 \times 10^{-29}$ & 0.9122 \\
\hline
\end{tabular}

\section{Impact Significance of the Panel Size on the Overlying Strata Permeability}

On the basis of the fitting function of permeability variation of weakly cemented mudstone and sandstone, the Fast Lagrangian Analysis of Continua 3D (FLAC ${ }^{3 D}$ ) (developed by Itasca International Inc., Minnesota, USA) numerical calculation model based on the actual geological conditions of the Yili No.4 Coal Mine was established. The strain-permeability variation functions of weakly cemented mudstone and sandstone were incorporated into the above numerical calculation model. Eventually, the effect of panel size on the permeability of overlying strata was analyzed.

\subsection{Calculation Scheme}

\subsubsection{Scheme Design}

The orthogonal test method was used to simulate the effect of the panel size (which included the mining height, panel width, and panel length) on the permeability of the overlying strata. For this purpose, three levels were set for the above three factors combined with the actual mining conditions of the particular panel 21103. Namely, three levels of mining height $(2.0 \mathrm{~m}, 3.5 \mathrm{~m}$, and $5.0 \mathrm{~m})$, panel 
width (100 m, $140 \mathrm{~m}$, and $200 \mathrm{~m})$, and panel length $(500 \mathrm{~m}, 1000 \mathrm{~m}$, and $1500 \mathrm{~m})$ were set. In this design, the panel lengths should be in the critical condition, which implies that the maximum subsidence reaches its maximum possible value. According to the orthogonal test principle, nine sets of modeling tests were required to incorporate the above three factors and three levels. Table 5 lists the particular parameters of the above test scheme.

Table 5. Orthogonal test scheme for the numerical modeling.

\begin{tabular}{cccc}
\hline Model No. & Mining Height $(\mathbf{m})$ & Panel Width $(\mathbf{m})$ & Panel Length $(\mathbf{m})$ \\
\hline 1 & 2.0 & 100 & 500 \\
2 & 2.0 & 140 & 1000 \\
3 & 2.0 & 200 & 1500 \\
4 & 3.5 & 100 & 1000 \\
5 & 3.5 & 140 & 500 \\
6 & 3.5 & 200 & 1500 \\
7 & 5.0 & 100 & 1500 \\
8 & 5.0 & 140 & 500 \\
9 & 5.0 & 200 & 1000 \\
\hline
\end{tabular}

\subsubsection{Numerical Model}

According to the above test design, the model of the permeability variation of different mined-out sizes of panel was established based on the actual geological conditions of the panel 21103. In this model, the Mohr-Coulomb criterion was employed to define the non-linear failure of rock materials, while the strain-permeability fitting functions of weakly cemented rock were used for the permeability calculation. The variation of permeability in the aquiclude of the overlying mudstone was described by the strain-permeability fitting function of weakly cemented mudstone, namely $k=(2.041-18.85 \varepsilon+$ $\left.72.72 \varepsilon^{2}-101.8 \varepsilon^{3}+48.46 \varepsilon^{4}\right) \times 10^{-14}$, and the remaining strata were controlled by the strain-permeability fitting function of weakly cemented sandstone, namely $k=\left(1.595-14.16 \varepsilon+54.18 \varepsilon^{2}-79.36 \varepsilon^{3}+\right.$ $\left.39.31 \varepsilon^{4}\right) \times 10^{-12}$. In addition, a monitoring surface was arranged between the mudstone aquiclude and sandstone to monitor the pore pressure difference and flow velocity at the bottom of the aquiclude. The measuring lines were arranged at intervals of $5 \mathrm{~m}$ parallel to the retreat direction, while the distance between the measuring points on the measuring lines was also $5 \mathrm{~m}$. The numerical model and layout of the measuring lines are shown in Figure 7.

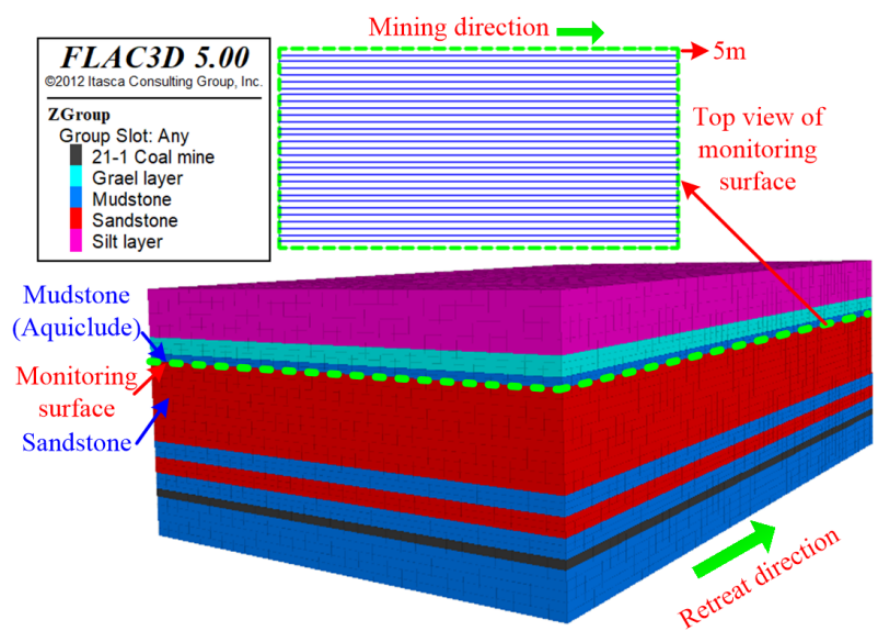

Figure 7. Numerical model and layout of measuring lines. 


\subsection{Numerical Simulation Results and Discussion}

The permeability distribution rules of the overlying strata in different modellings are basically similar. The modeling results for model number 8 (as shown in Table 5) were taken as an example to analyze the variation rules of permeability of the overlying strata in weakly cemented strata after mining. The permeability distribution of the overlying strata after mining in number 8 is shown in Figure 8. It can be seen in Figure 8 that the permeability distribution after mining can be subdivided into the following three zones: (I) the permeability reduction zone; (II) the permeability restoring zone; and (III) the permeability high-increment zone.

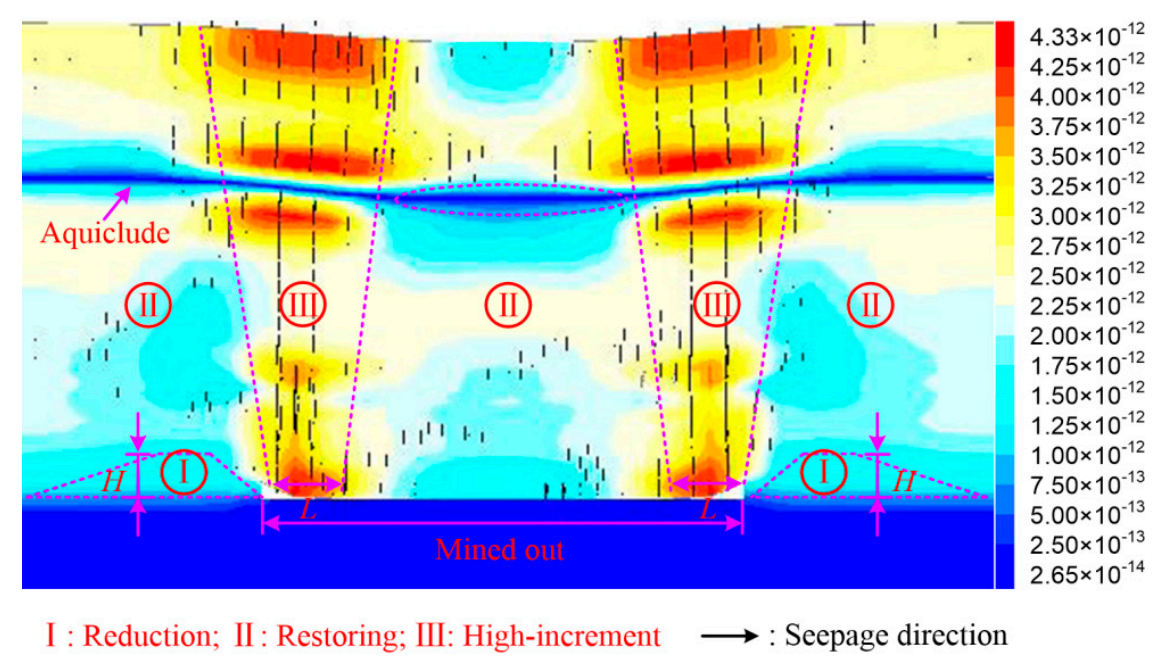

Figure 8. Permeability distribution of overlying strata in model number 8.

The permeability reduction zone (zone I) is mainly distributed in the upper and lower ends of the work surface, with a trapezoidal distribution which is $7.87 \mathrm{~m}$ high in the vertical plane above the coal seam floor, roughly 1.57 times of the mining height. The permeability of the overlying strata in zone I ranges from $1.21 \times 10^{-12} \mathrm{~cm}^{2}$ to $6.52 \times 10^{-13} \mathrm{~cm}^{2}$, which indicates that the ratio of post-mining permeability to initial permeability ( $\mathrm{P} / \mathrm{I}$ ratio) ranges from 0.31 to 0.53 . The strain-based permeability decrease is triggered by the rock compaction which is associated with the abutment pressure effect in mining operations.

The permeability restoring zone (zone II) is mainly distributed in the middle of the goaf and the overlying strata on both sides of the panel. The permeability of the overlying strata in zone II exhibits a gradual reduction after a sharp rise, corresponding to the gradual compaction after overburden collapse or fracture during the mining operation. Thus, the respective $\mathrm{P} / \mathrm{I}$ ratio ranges from 0.49 to 2.82 .

The V-shaped permeability high-increment zone (zone III) is mainly located at the upper and lower ends of the working surface. The lower part above the mined-out area is about $19.44 \mathrm{~m}$ long, accounting for about $13.89 \%$ of the total length of the panel. The P/I ratio in zone III ranges from 2.56 to 12.36 . The permeability of the overlying strata increases sharply because the overlying strata at the upper and lower ends of the work surface undergo drastic tensile failure in the horizontal plane, forming a tensile-fractured zone, which is also highly permeable

The post-mining permeability of the aquiclude in zone III is higher than that in the middle of the goaf. Due to the above permeability changes with mining operation, the aquiclude in zone III looks like a concave lens, where water-resistance strata get thinner after mining. Thus, the overlying water may easily pass through the aquiclude and flow downward to the goaf. Meanwhile, the aquiclude in zone II looks like a convex lens, where water-resistance strata get thicker after mining because of the permeability properties of weakly-cemented rock suffering compaction. 


\subsection{Impact Significance of Panel Size}

Pore pressure difference plays an important role in driving water flow in porous rock, while flow velocity is one of the key parameters describing the flow field in rock. Thus, the maximum pore pressure difference $U_{\max }$, maximum flow velocity $V_{\max }$, and development height $H_{\mathrm{p}}$ in the plastic zone of overlying strata were simulated and recorded via the monitoring line of the upper mudstone aquiclude with different models. The results for each model are summarized in Table 6. Then, the $U_{\max }$ and $V_{\max }$ values of the upper mudstone aquiclude of the overlying strata were selected as key indices to analyze the impact significance of the mining height, panel width, and panel length on post-mining permeability of the overlying strata by using a single-factor variance analysis method. More details are given in Table 7.

Table 6. Numerical simulation results for various indices.

\begin{tabular}{ccccc}
\hline Model & $\boldsymbol{U}_{\text {max }}(\mathbf{M P a})$ & $\boldsymbol{V}_{\max }\left(\mathbf{1 0}^{\mathbf{- 9}} \mathbf{~} \mathbf{s}\right)$ & $\boldsymbol{H}_{\mathbf{p}} \mathbf{( m )}$ & Note \\
\hline $1(2.0 \mathrm{~m} \times 100 \mathrm{~m} \times 500 \mathrm{~m})$ & 0.35 & 4.83 & 21.00 & \\
$2(2.0 \mathrm{~m} \times 140 \mathrm{~m} \times 1000 \mathrm{~m})$ & 0.56 & 6.75 & 28.67 & \\
$3(2.0 \mathrm{~m} \times 200 \mathrm{~m} \times 1500 \mathrm{~m})$ & 1.23 & 8.56 & 37.14 & \\
$4(3.5 \mathrm{~m} \times 100 \mathrm{~m} \times 1000 \mathrm{~m})$ & 1.07 & 11.50 & 46.12 & \\
$5(3.5 \mathrm{~m} \times 140 \mathrm{~m} \times 500 \mathrm{~m})$ & 1.50 & 29.90 & 68.33 & \\
$6(3.5 \mathrm{~m} \times 200 \mathrm{~m} \times 1500 \mathrm{~m})$ & 2.34 & 32.80 & 82.56 & \\
$7(5.0 \mathrm{~m} \times 100 \mathrm{~m} \times 1500 \mathrm{~m})$ & 1.75 & 112.00 & 85.72 & Aquiclude failure \\
$8(5.0 \mathrm{~m} \times 140 \mathrm{~m} \times 500 \mathrm{~m})$ & 1.92 & 132.00 & 91.93 & Aquiclude failure \\
$9(5.0 \mathrm{~m} \times 200 \mathrm{~m} \times 1000 \mathrm{~m})$ & 3.86 & 139.90 & 125.00 & Aquiclude failure \\
\hline
\end{tabular}

Table 7. Variance analysis results for the maximum pore pressure difference $U_{\max }$.

\begin{tabular}{ccccccc}
\hline \multicolumn{7}{c}{ Dependent Variable: The Maximum Pore Pressure Difference $U_{\text {max }}$} \\
\hline Source & Type III SS & df & MSE & $\boldsymbol{F}$ & Sig. & Significance Grade \\
\hline Calibration model & 8.622 a & 6 & 1.437 & 12.710 & 0.075 & \\
Intercept & 23.620 & 1 & 23.620 & 208.900 & 0.005 & Highest \\
Mining height & 4.843 & 2 & 2.422 & 21.418 & 0.045 & high \\
Panel width & 3.180 & 2 & 1.590 & 14.063 & 0.066 & Slight \\
Panel length & 0.367 & 2 & 0.184 & 1.624 & 0.381 & \\
Error & 0.226 & 2 & 0.113 & & & \\
Sum & 32.468 & 9 & & & & \\
Corrected sum & 8.848 & 8 & & &
\end{tabular}

As shown in Table 7, the variance $F$ for the effect of the mining height, panel width, and panel length on the maximum pore pressure difference $U_{\max }$ assessed as 21.418, 14.063, and 1.624, respectively. Thus, the influence of various factors on the permeability of overlying strata is graded in decreasing order as follows: mining height $>$ panel width $>$ panel length. The significance values $(P)$ of mining height, panel width, and panel length are $0.045,0.066$, and 0.381 , respectively. At $P_{\text {mining height }}=0.045$ $<0.05<P_{\text {mining height }}=0.066<0.10$, the mining height has a stronger impact on the permeability of the overlying strata than that of the panel width, while the value $P_{\text {mining height }}=0.381>0.10$ indicates that the panel length has a slight impact on the post-mining permeability of aquiclude.

The results of the variance analysis, with the maximum flow velocity $V_{\max }$ used as the index, are shown in Table 8. Here, variance $F$ values of the effect of the mining height, panel width, and panel length on the maximum flow velocity of the overlying strata are $738.094,17.876$, and 4.111 , respectively. It can be concluded that the influence of various factors on the permeability of overlying strata is graded in decreasing order as follows: mining height $>$ panel width $>$ panel length. The significance values $(P)$ of the mining height, panel width, and panel length are $0.001,0.053$, and 0.196 , respectively. 
Since $P_{\text {mining height }}=0.001<0.05$, the impact of mining height on the flow velocity is the highest. The value $0.05<P_{\text {mining height }}=0.053<0.10$ implies that the panel width has a strong impact on the flow velocity, while, $P_{\text {mining height }}=0.196>0.10$ suggests that the panel length has a slight impact on the flow velocity.

Table 8. Variance analysis results for the maximum flow velocity $V_{\max }$.

\begin{tabular}{ccccccc}
\hline \multicolumn{7}{c}{ Dependent Variable: The Maximum Flow Velocity $V_{\text {max }}$} \\
\hline Source & Type III SS & df & MSE & $\boldsymbol{F}$ & Sig. & Significance Grade \\
\hline Calibration model & $26336.866^{\mathrm{a}}$ & 6 & 4389.478 & 252.283 & 0.004 & \\
Intercept & 25412.611 & 1 & 25412.611 & 1460.578 & 0.001 & \\
Mining height & 25684.212 & 2 & 12842.106 & 738.094 & 0.001 & Highest \\
Panel width & 622.063 & 2 & 311.031 & 17.876 & 0.053 & High \\
Panel length & 143.065 & 2 & 71.532 & 4.111 & 0.196 & Slight \\
Error & 34.798 & 2 & 17.399 & & & \\
Sum & 51784.275 & 9 & & & & \\
Corrected sum & 26371.664 & 8 & & & & \\
\hline
\end{tabular}

${ }^{a} R^{2}=0.999$ (adjustment $R^{2}=0.995$ ). Where Type III SS is Type III sum of squares, df is degrees of freedom, MSE is mean squared error, $F$ is group variance, and Sig. is significance.

Taking $U_{\max }$ and $V_{\max }$ of the aquiclude as indices, the influence of various factors on the permeability of the overlying strata under mining in decreasing order is as follows: mining height, panel width, and panel length. Therefore, when determining the panel size parameters in terms of the permeability of the overlying strata, the mining height and length of the panel should be considered first. However, when the advancing length exceeds $500 \mathrm{~m}$, it has a relatively slight impact on the permeability of the overlying strata.

\subsection{Determination of a Reasonable Panel Size}

The coal seam of panel 21103 of the Yili No.4 Coal Mine in Xinjiang, China, deposits $80 \mathrm{~m}$ below the upper mudstone aquiclude. The thickness of the aquiclude is $5 \mathrm{~m}$, and the maximum flow velocity of the aquiclude before mining is $V_{0}=3.17 \times 10^{-8} \mathrm{~m} / \mathrm{s}$. The reasonable size of panel 21103 in the Yili No.4 mine should be based on the results of impact significance analysis and the height of the plastic zone in the overlying strata. At the mining height of $5.0 \mathrm{~m}$, the maximum flow velocity of the aquiclude in each scheme exceeded $V_{0}$, and the development height of the plastic zone in the overlying strata also exceeded $85 \mathrm{~m}$ (as shown in Table 6), which indicates that the water-conducting fractured zone in the overlying strata developed above the mudstone aquiclude. The resultant scenarios imply that the aquiclude was fractured, and the flow velocity increased sharply. Thus, the mining height of panel 21103 should be less than $5.0 \mathrm{~m}$. At the mining height of $3.5 \mathrm{~m}$, the panel width was $200 \mathrm{~m}$, and the panel length was $1500 \mathrm{~m}$ (as shown in Table 6), with the maximum flow velocity of the aquiclude $V_{\max }=3.28 \times 10^{-8} \mathrm{~m} / \mathrm{s}>V_{0}$. Meanwhile, the plastic zone height in the overlying strata was $82.56 \mathrm{~m}$, the water-conducting fracture developed in the middle and upper parts of the aquiclude, and the flow velocity in the aquiclude started to increase, which caused a risk of water resource damage. Therefore, in order to ensure that the aquiclude is stable and the phreatic water resources are not damaged during the mining operation, the panel width should be less than $200 \mathrm{~m}$. At mining height, panel width, and panel length values of $3.5 \mathrm{~m}, 140 \mathrm{~m}$ and $500 \mathrm{~m}$, respectively (as shown in Table 6), the maximum flow velocity of the aquiclude is derived as $V_{\max }=2.99 \times 10^{-8} \mathrm{~m} / \mathrm{s}<V_{0}$. The plastic zone in the overburden was $68.33 \mathrm{~m}$ thick and located at $11.67 \mathrm{~m}$ below the aquiclude. In this case, the water-resisting property in the aquiclude remained stable, while the flow velocity was still low, without the loss of aquifer water resources. In addition, since the impact of an advance length exceeding $500 \mathrm{~m}$ on the permeability of the overlying strata is considered slight, the length of the panel should be appropriately increased so as to reduce tunneling works, equipment recovering periods, and production cost. Based on the above 
simulation results and their discussion, the proposed dimensions of the panel 21103 of the Yili No.4 Coal Mine (mining height $\times$ panel width $\times$ panel length) are $3.5 \mathrm{~m} \times 140 \mathrm{~m} \times 1500 \mathrm{~m}$.

\section{Field Observations on Water Level}

The actual mining size of the 21103 panel of the Yili No.4 Coal Mine are as follows: mining height of $3.5 \mathrm{~m}$, panel width of $115 \mathrm{~m}$, and panel length of $1710 \mathrm{~m}$, which are basically consistent with the simulation results. A vertical borehole was drilled at the distance of $1265 \mathrm{~m}$ ahead of the setup room (as shown in Figure 9) for continuous monitoring of the water level variation during the mining operation.

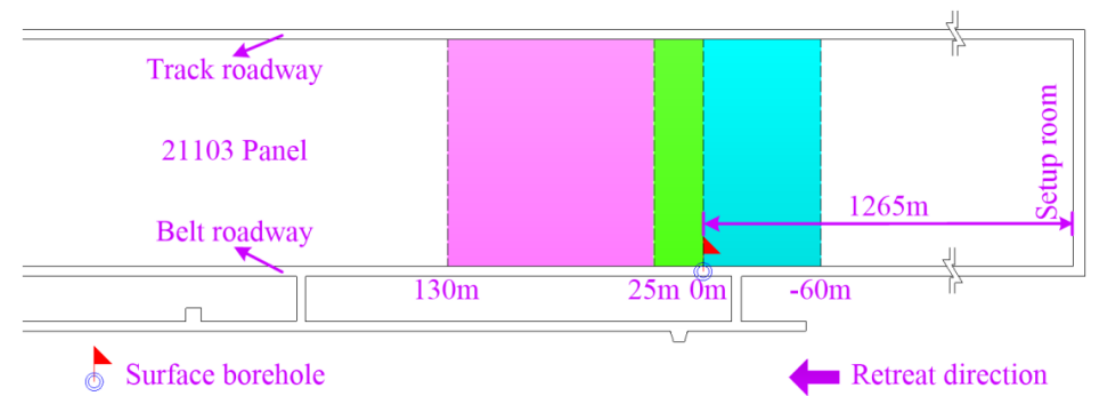

Figure 9. The layout of boreholes for water level monitoring.

The monitoring results are shown in Figure 10. The water level began to drop when the panel was $60 \mathrm{~m}$ away from the borehole, which can be associated with the subsidence basin above the mined-out area. The water flow into the subsidence basin, and tensile strains at the basin boundaries increase the permeability and contribute to the water level drop. When the panel was mined below the borehole, the water level dropped by the maximum value of $3.0 \mathrm{~m}$, with the surface subsidence exceeding $50 \%$ of the final value. Furthermore, when the working face reached a distance of $25 \mathrm{~m}$ from the borehole, the water level reached its lowest value and then began to rise, with the surface subsidence being the maximum. When the working face was $130 \mathrm{~m}$ away from the borehole, the water level rose back to only $0.35 \mathrm{~m}$ below the original level, which means that the impact of underground mining on the water level around the borehole was slight at that time. Afterwards, the water level exhibited no significant changes.

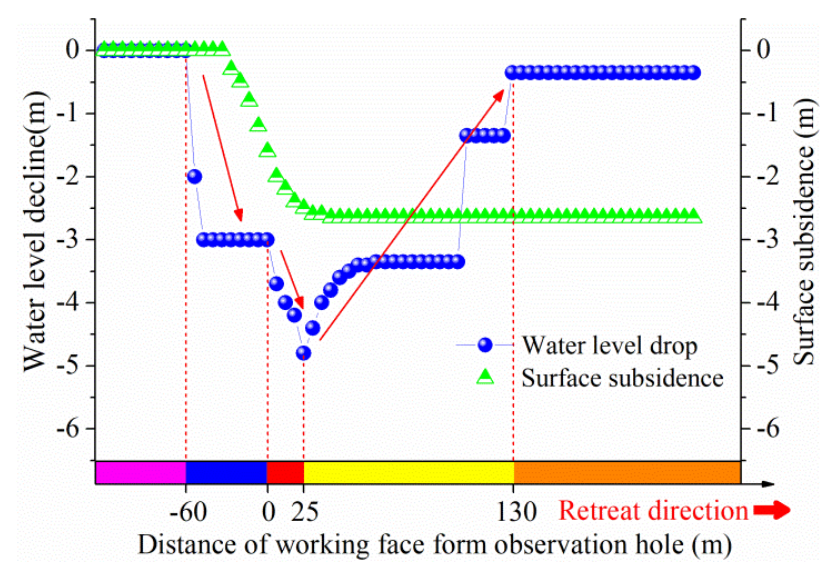

Figure 10. The water level variation in the borehole.

The above field observations results prove that the water level dropped when the working face approached the borehole, but gradually recovered to nearly the original level after the working face passed through the borehole. They also confirmed that mining-induced fractures provided no sufficient 
channels for water to flow from the aquifer into the goaf, and the aquiclude remained impermeable during the mining operation.

\section{Conclusions}

The performed permeability tests proved that the permeability characteristics of weakly cemented mudstone and sandstone are directly related to their microstructure and mineral composition. The porosity and poor cementation contribute to the post-peak permeability reduction below the initial permeability level during the total stress-strain process. Since mudstone was rich in clay minerals, its permeability was lower by two orders of magnitude than that of sandstone, and its water resistance was high. After failure, the sandstone residual permeability was $59.42 \%$ of its initial value. Affected by the porosity of sandstone, the stress plateau appeared after entering the plastic flow stage. Due to contrary impacts of porosity closure, leading to permeability reduction and particle crushing and subsequently to permeability rise, the permeability was only $34.80 \%$ of the initial value.

The numerical simulation results confirmed that the permeability distribution in the weakly cemented overlying strata could be subdivided into three zones: permeability reduction zone I, permeability reduction zone II, and permeability high-increment zone III. Of these, zone I was mainly distributed at the upper and lower ends of the work surface, with a trapezoidal distribution. Zone II was mainly located in the middle of the goaf and in the overlying strata on both sides of the panel, while zone III was V-shaped and located above the upper and lower ends of the work surface. Water in the aquifer mainly passed through the aquiclude along zone III and flew vertically downward to the goaf. Meanwhile, the aquiclude permeability in the horizontal tensile zone exceeded that in the compaction zone in the middle of the goaf.

Taking maximum pore pressure difference and maximum flow velocity as key indices, the influence of various factors on the permeability of the overlying strata was graded in decreasing order as follows: mining height, panel width, and panel length. Thus, the proposed dimensions of panel 21103 are $3.5 \mathrm{~m}$ in mining height, $140 \mathrm{~m}$ in panel width, and $1500 \mathrm{~m}$ in panel length. The field observation of the water level proved that the aquiclude remained impermeable during the retreating period of panel 21103 of $3.5 \mathrm{~m}$ in height, $115 \mathrm{~m}$ in width, and $1710 \mathrm{~m}$ in length. Although the aquifer water level dropped at the early stage, it gradually recovered when the overlying strata parameters became stable.

Supplementary Materials: The following are available online at http://www.mdpi.com/2071-1050/12/6/2396/s1, Table S1: Research data.

Author Contributions: G.F. designed the overall concept of the study; S.Z. analyzed the data and composed the paper; B.C. completed the permeability test of weakly cemented rocks; D.Z. adjusted the structure of the paper and modified the research content; C.Z. modified the article structure and corrected spelling, grammar, and verb tense errors to improve the readability. All authors have read and agreed to the published version of the manuscript.

Funding: This work was financially supported by the Fundamental Research Funds for the Central Universities [grant number 2017XKQY073].

Acknowledgments: The authors are grateful to the Yili No.4 coal mine in Xinjiang for the supports of the collection of rock samples and the water level monitoring of aquifer on-site, as well as the helpful comments provided by the anonymous reviewers.

Conflicts of Interest: The authors declare that they have no conflicts of interest.

\section{References}

1. Du, F.; Syd, S.P. The state-of-the-art and thought of automated longwall in the United States. J. China Univ. Min. Technol. 2018, 47, 949-956. [CrossRef]

2. Cao, D.; Huang, C.; Wu, J.; Li, H.; Zhang, Y. Environment carrying capacity evaluation of coal mining in Shanxi Province. Adv. Mater. Res. 2012, 518-523, 1141-1144. [CrossRef]

3. Xian, W.; Zhou, W.; Shao, H. Study on the ecological carrying capacity in mining areas a case study in Panxi mining concentrated area. In Proceedings of the 1st International Conference on Information Science and Engineering (ICISE2009), Nanjing, China, 26-28 December 2009; pp. 2193-2197. 
4. Li, Y.; Peng, S.S.; Zhang, J. Impact of longwall mining on groundwater above the longwall panel in shallow coal seams. J. Rock Mech. Geotech. Eng. 2015, 7, 298-305. [CrossRef]

5. Rashid, H.; Hossain, S.; Urbi, Z.; Islam, S. Environmental impact of coal mining: A case study on the Barapukuria Coal Mining Industry, Dinajpur, Bangladesh. Middle East J. Sci. Res. 2014, 21, 268-274. [CrossRef]

6. Xu, K.; Tan, K.; Du, P. Assessment of the ecological carrying capacity based on high resolution data: A case study of Yuxian, China. In Proceedings of the 2016 Fourth International Workshop on Earth Observation and Remote Sensing Applications Assessment, Guangzhou, China, 4-6 July 2016; pp. 405-409.

7. Zhang, C.; Mitra, R.; Oh, J.; Canbulat, I.; Hebblewhite, B. Numerical analysis on mining-induced fracture development around river valleys. Int. J. Mining, Reclam. Environ. 2018, 32, 463-485. [CrossRef]

8. Zhang, D.; Fan, G.; Liu, Y.; Ma, L. Field trials of aquifer protection in longwall mining of shallow coal seams in China. Int. J. Rock Mech. Min. Sci. 2010, 47, 908-914. [CrossRef]

9. Zhang, S.; Fan, G.; Zhang, D.; Li, Q. Physical simulation research on evolution laws of clay aquifuge stability during slice mining. Environ. Earth Sci. 2018, 77, 1-10. [CrossRef]

10. Zhang, S.; Fan, G.; Zhang, D.; Chen, M.; Zhang, C. Study on material properties and similar material proportion of weakly cemented water-resisting strata. Arab. J. Geosci. 2019, 12, 1-13. [CrossRef]

11. Wang, S.M.; Huang, Q.X.; Fan, L.M.; Wang, W.K. Coal Mining and Ecological Water Level Protection in Ecologically Fragile Areas; Science China Press: Beijing, China, 2010.

12. Zhang, C.; Mitra, R.; Oh, J.; Hebblewhite, B. Analysis of Mining-induced Valley Closure Movements. Rock Mech. Rock Eng. 2016, 49, 1923-1941. [CrossRef]

13. Adhikary, D.P.; Guo, H. Modelling of longwall mining-Induced strata permeability change. Rock Mech. Rock Eng. 2015, 48, 345-359. [CrossRef]

14. Meng, Z.; Shi, X.; Li, G. Deformation, failure and permeability of coal-bearing strata during longwall mining. Eng. Geol. 2016, 208, 69-80. [CrossRef]

15. Khanal, M.; Guo, H.; Adhikary, D. 3D uumerical study of underground coal mining induced strata deformation and subsequent permeability change. Geotech. Geol. Eng. 2019, 37, 235-249. [CrossRef]

16. Wachtel, T.; Quaranta, J.; van Zyl, D.; Siriwardane, H. Event tree analysis for room and pillar mining affecting permeability beneath surface bodies of water. Georisk Assess. Manag. Risk Eng. Syst. Geohazards 2014, 8, 106-116. [CrossRef]

17. Das, S.K. Observations and classification of roof strata behaviour over longwall coal mining panels in India. Int. J. Rock Mech. Min. Sci. 2000, 37, 585-597. [CrossRef]

18. Nourani, M.; Meyer, A.G.; Lorentzen, H.J.; Sigalas, L.; Taheriotaghsara, M.; Olsen, D.; Stemmerik, L. Determination of the overburden permeability of North Sea Chalk. Rock Mech. Rock Eng. 2019. [CrossRef]

19. Poulsen, B.A.; Adhikary, D.; Guo, H. Simulating mining-induced strata permeability changes. Eng. Geol. 2018, 237, 208-216. [CrossRef]

20. Wang, W.X.; Sui, W.H.; Faybishenko, B.; Stringfellow, W.T. Permeability variations within mining-induced fractured rock mass and its influence on groundwater inrush. Environ. Earth Sci. 2016, 75, 326. [CrossRef]

21. Karacan, C.Ö.; Esterhuizen, G.S.; Schatzel, S.J.; Diamond, W.P. Reservoir simulation-based modeling for characterizing longwall methane emissions and gob gas venthole production. Int. J. Coal Geol. 2007, 71, 225-245. [CrossRef]

22. Karacan, C.Ö.; Goodman, G. Hydraulic conductivity changes and influencing factors in longwall overburden determined by slug tests in gob gas ventholes. Int. J. Rock Mech. Min. Sci. 2009, 46, 1162-1174. [CrossRef]

23. Rezaei, M.; Hossaini, M.F.; Majdi, A. A time-independent energy model to determine the height of destressed zone above the mined panel in longwall coal mining. Tunn. Undergr. Sp. Technol. 2015, 47, 81-92. [CrossRef]

24. Palchik, V. Formation of fractured zones in overburden due to longwall mining. Environ. Geol. 2003, 44, 28-38. [CrossRef]

25. Palchik, V. Bulking factors and extents of caved zones in weathered overburden of shallow abandoned underground workings. Int. J. Rock Mech. Min. Sci. 2015, 79, 227-240. [CrossRef]

26. Majdi, A.; Hassani, F.P.; Nasiri, M.Y. Prediction of the height of destressed zone above the mined panel roof in longwall coal mining. Int. J. Coal Geol. 2012, 98, 62-72. [CrossRef]

27. Weng, L.; Luan, Y.; Luan, H.; Zhu, C. Prediction method of water flowing fractured zone height in Tengnan Mining Area. Electron. J. Geotech. Eng. 2016, 21, 7457-7467. 
28. Feng, S.; Sun, S.; Lv, Y.; Lv, J. Procedia engineering research on the height of water flowing fractured zone of fully mechanized caving mining in extra-thick coal seam. Procedia Eng. 2011, 26, 466-471. [CrossRef]

29. Follington, I.L.; Isaac, A.K. Failure zone development above longwall panels. Min. Sci. Technol. 1990, 10, 103-116. [CrossRef]

30. Dumpleton, S. Effects of longwall mining in the Selby Coalfield on the piezometry and aquifer properties of the overlying Sherwood Sandstone. Geol. Soc. Loadon Spec. Publ. 2002, 198, 75-88. [CrossRef]

31. Fan, G.; Zhang, D. Mechanisms of aquifer protection in underground coal mining. Mine Water Environ. 2015, 34, 95-104. [CrossRef]

32. Zhang, D.; Fan, G.; Ma, L.; Wang, X. Aquifer protection during longwall mining of shallow coal seams: A case study in the Shendong Coal field of China. Int. J. Coal Geol. 2011, 86, 190-196. [CrossRef]

33. Fan, G.; Chen, M.; Zhang, D.; Wang, Z.; Zhang, S.; Zhang, C.; Li, Q.; Cao, B. Experimental study on the permeability of weakly cemented rock under different stress states in triaxial compression tests. Geofluids 2018, 2018, 1-9. [CrossRef]

34. Liu, D.; Liu, Y.; Zhao, C. Experimental study on the characteristics of permeability in the all failure process of mudstone. J. Xi'an Univ. Sci. Tehnol. 2015, 35, 78-82. [CrossRef]

35. Zhang, R.; Jiang, Z.; Sun, Q.; Zhu, S. The relationship between the deformation mechanism and permeability on brittle rock. Nat. Hazards 2013, 66, 1179-1187. [CrossRef]

36. Olsson, W.A.; Holcomb, D.J. Compaction localization in porous rock. Geophys. Res. Lett. 2000, 27, 3537-3540. [CrossRef]

37. Baud, P.; Reuschlé, T.; Ji, Y.; Cheung, C.S.N.; Wong, T. Mechanical compaction and strain localization in Bleurswiller sandstone. J. Geophys. Res. Solid Earth 2015, 120, 6501-6522. [CrossRef]

(C) 2020 by the authors. Licensee MDPI, Basel, Switzerland. This article is an open access article distributed under the terms and conditions of the Creative Commons Attribution (CC BY) license (http://creativecommons.org/licenses/by/4.0/). 